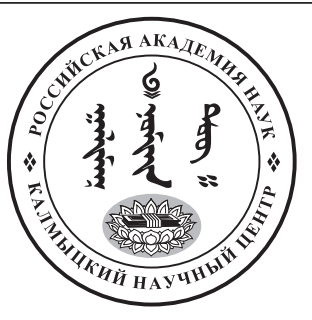

Published in the Russian Federation

Oriental Studies (Previous Name: Bulletin of the Kalmyk Institute

for Humanities of the Russian Academy of Sciences)

Has been issued as a journal since 2008

ISSN: 2619-0990; E-ISSN: 2619-1008

Vol. 13, Is. 1, pp. 133-149, 2020

DOI: 10.22162/2619-0990-2020-47-1-133-149

Journal homepage: https://kigiran.elpub.ru

УДК 821.512 .37

\title{
Два ойратских списка \\ «Сутры, отвращающей [влияние] плохих снов»
}

\author{
Саглара Викторовна Мирзаева ${ }^{1}$
}

${ }^{1}$ Калмыцкий научный центр РАН (д. 8, ул. И. К. Илишкина, 358000 Элиста, Российская Федерация) научный сотрудник

D 0000-0002-8542-0260. E-mail: kundgabo@list.ru

(C) КалмНЦ РАН, 2020

(C) Мирзаева С. В., 2020

Аннотация. Цель данной статьи - введение в научный оборот двух ойратских списков «Сутры, отвращающей [влияние] плохих снов», представляющей собой известное в монгольской традиции сочинение по снотолкованию, а также анализ содержания текстов в сопоставлении с данными по этнографии монгольских народов в диахронном аспекте. Исследование проблемы основывается на методах сравнительного и сопоставительного анализа, а использование метода исторической реконструкции позволит схематично представить функционирование сонника в буддийских ритуалах. В результате исследования были сделаны следующие вblвoдbl: рассмотренные ойратские рукописи из Научного архива КалмНЦ РАН и цифровой библиотеки ойратских рукописей фонда «Тод номын гэрэл» представляют собой списки популярного сонника, широко представленного и на классическом монгольском, самые ранние образцы которого относятся к первой половине XVII в. Анализ содержания ойратских рукописей позволяет выделить в них три раздела: плохие сны с людьми; плохие сны с птицами и животными и плохие сны с определенными ситуациями, предвещающими смерть. Некоторые из рассмотренных примет сохраняют свое бытование в современной культуре монгольских народов. Большая часть из них основана на принципе имитативной магии, а также восприятии единого пространства сновидений и мира предков как мира с противоположной ориентацией. Анализ этнографических данных по традиции снотолкования у монгольских народов показывает, что раньше она была связана с шаманизмом, но впоследствии была включена в состав буддийской обрядности. Способы нейтрализации дурных сновидений также претерпели изменения: из сложного ритуала они трансформировались в чтение специальных буддийских текстов без ритуального сопровождения. Сопоставление ойратских списков сонника с тибетскими текстами, имеющими аналогичное название, показало отсутствие сходства в системе образов неблагоприятных сновидений и методах их нейтрализации, что затрудняет определение принадлежности «Сутры, отвращающей [влияние] плохих снов» к переводной литературе или оригинальной монголоязычной письменной традиции. В приложениях приведены транслитерация, перевод и факсимиле рукописи из НА КалмНЦ РАН. 
Ключевые слова: «Сутра, отвращающая [влияние] плохих снов», ойратская рукопись, сонник, нейтрализация дурных сновидений, приметы

Благодарность. Исследование выполнено при финансовой поддержке гранта в форме субсидии из федерального бюджета, выделяемой для государственной поддержки научных исследований, проводимых под руководством ведущего ученого (проект «От палеогенетики до культурной антропологии: комплексное интердисциплинарное исследование традиций народов трансграничных регионов: миграции, межкультурное взаимодействие и картина мира»).

Для цитирования: Мирзаева С. В. Два ойратских списка «Сутры, отвращающей влияние плохих снов» // Oriental Studies. 2020. Т. 13. № 1. С. 133-149. DOI: 10.22162/2619-0990-202047-1-133-149

UDC 821.512 .37

\title{
Sütra [Averting Effects] of Bad Dreams: Two Oirat Manuscript Copies Revisited
}

\author{
Saglara V. Mirzaeva ${ }^{1}$ \\ ${ }^{1}$ Kalmyk Scientific Center of the RAS (8, Ilishkin St., Elista 358000, Russian Federation) \\ Research Associate
}

iD 0000-0002-8542-0260. E-mail: kundgabo@list.ru

CKalmSC RAS, 2020

(C) Mirzaeva S. V., 2020

\begin{abstract}
Goals. The article introduces two Oirat manuscript copies of the Sütra [Averting Effects] of Bad Dreams, a well-known dream book of the Mongolian tradition, and analyzes the texts diachronically comparing their contents to available sources dealing with Mongolic ethnography. Methods. The study employs the comparative method and that of historical reconstruction, the latter being most instrumental in outlining the functioning of this dream-book in Buddhist rituals. Results. Two analyzed manuscripts are copies of one dream-book once widely spread in Classical Mongolian too (earliest samples date back to the early/mid-1 $17^{\text {th }}$ century). Our analysis reveals the texts consist of three sections, namely: bad dreams with humans; bad dreams with birds, animals; and bad dreams with certain situations predicting death. Some of the omens are still inherent to contemporary Mongolic cultures, most of the former based on the principle of imitative and reflection magic, an integrated space of dream and ancestors' worlds viewed as one with opposite orientation. The analysis of ethnographic data on the tradition of Mongolic dream interpretation attests to the latter had initially been associated with shamanistic practices but was subsequently incorporated into a Buddhist ritual framework. Means to avert bad dreams were transformed accordingly: complex rituals were replaced by mere reciting of special Buddhist texts without accompanying exercises. The comparison of Oirat manuscripts to Tibetan texts shows a big difference between the dream interpretation systems and respective averting methods, which complicates attempts to define the sūtra as a translated work or original Mongolic ones. The paper transliterates, translates, and supplements a facsimile of the manuscript stored in the Kalmyk Scientific Center (RAS).

Keywords: Sūtra [Averting Effects] of Bad Dreams, Oirat manuscript, dream-book, neutralization of bad dreams, omens

Acknowledgments: The reported study was funded by government grant in the form of federal budget subsidy aimed to support scientific research directed by the Leading Scientist - project name 'From Paleogenetics to Cultural Anthropology: Comprehensive Interdisciplinary Research of Peoples and Traditions of Cross-Border Regions - Migrations, Cross-Cultural Interactions and Worldviews'. For citation: Mirzaeva S. V. Sütra [Averting Effects] of Bad Dreams: Two Oirat Manuscript Copies Revisited. Oriental Studies. 2020. Vol. 13. No. 1. Pp. 133-149. (In Russ.). DOI: 10.22162/2619-09902020-47-1-133-149
\end{abstract}




\section{Введение}

Образцы ойратского «ясного письма», созданного в середине XVII в. известным просветителем Зая-пандитой Намкай Джамцо, в исследовательской литературе традиционно рассматриваются в основном в рамках литературоведческих и лингвистических дисциплин. Однако требования современной науки обуславливают необходимость использования в современном монголоведении новых, междисциплинарных, подходов. Одним из интересных направлений культурной антропологии, методы которой приложимы и к изучению письменных памятников, является так называемая «история повседневности». Предмет ее изучения составляет сфера человеческой обыденности, различные категории которой получили отражение и в памятниках средневековой монгольской литературы.

Материалом для подобного исследования могут служить буддийские ритуальные сочинения - молитвенные тексты подношения воскурений санг и золотого напитка серкем, астрологические и гадательные тексты, в которые входили сборники примет и сонники. Их чтение имело целью прежде всего призывание благоденствия и «отвращение» неблагоприятствующих факторов. Приметы и сновидения расценивались как определенные знаки, интерпретация которых позволяла предугадать будущие события и, если они носили отрицательный характер, «отвратить» или нейтрализовать негативные последствия. С помощью анализа таких памятников можно проследить, какие категории в сознании представителей монгольских народов относились к благоприятным, а какие характеризовались как негативные.

Приметы как часть традиционного мировосприятия монгольских народов описывались в трудах У. Душана [Душан 2016], A. Рона-Таша [Róna-Tas 1972], К. Хэмфри [Humphrey 1976], Т. Г. Борджановой (Басанговой) [Борджанова 2007], Э. П. Бакаевой [Бакаева 2003; Бакаева 2009], Г. Р. Галдановой [Галданова 1987], Т. И. Шараевой [Шараева 2011], А. Д. Цендиной [Цендина 2019] и др. Символика сновидений в этих трудах затрагивалась лишь в общем контексте гадательной практики и толкования примет, но не рассматривалась отдельно. Исключение составляет монография Е. И. Рабиновича «Сны Пробужденных: сон и сновидения в культуре, религии, политике Тибета» [Рабинович 2013], в которой представлены ценные сведения по культурной модели сновидений в монгольской и бурятской традициях.

Присутствие в монголоязычном письменном наследии сочинений, посвященных толкованию снов, обуславливает актуальность исследования, в котором рассматривается категория сновидений в монгольской традиционной культуре. Одно из таких сочинений — «Сутра, отвращающая [влияние] плохих снов» (монг. maүu jegüden qariłulqu sudur orošibai, ойр. тои züdöӥn xariulxu sudur orošiboi), два ойратских списка которого были обнаружены в Научном архиве Калмыцкого научного центра РАН (далее - НА КалмНЦ РAН) [MZ 1] и цифровой библиотеке ойратских рукописей фонда «Тод номын гэрэл» [MZ 2]. Монгольские и ойратские списки этого сочинения представлены во многих фондохранилищах [Сазыкин 1988: 346-347 (№№ 1970-1975); Сазыкин 2001: 211-212 (№ 3328, 3329); Орлова 2002: 28, 32, 61], самые ранние из них относятся к первой половине XVII в. [Chiodo 2000: 217-223].

Данное исследование ставит своей целью ввод в научный оборот двух ойратских списков «Сутры, отвращающей [влияние] плохих снов», а также анализ содержания текстов в сопоставлении с данными по этнографии монгольских народов в диахронном аспекте. Кроме того, важным представляется рассмотреть проблематику происхождения сочинения, обратившись к тибетской литературной традиции. Исследование проблемы основывается на методах сравнительного и сопоставительного анализа, а использование метода исторической реконструкции позволит схематично представить функционирование сонника в буддийских ритуалах.

Первый из привлекаемых текстов (без названия) [MZ 1] хранится в Фонде $15 \mathrm{HA}$ 
КалмНЦ РАН под номером 413. Рукопись небольшого формата $(16,5 * 8,8 \mathrm{~cm})$, состоит из трех листов, разорванных посередине по линии сгиба и склеенных. Листы оборваны по краям. На титульном листе рукописи оригинальное название текста отсутствует, ручкой приписан русский перевод названия «Молитва от дурных снов». На л. 1b в начале текста приводится четырехчастная молитвенная формула поклонения Учителю, Будде, Дхарме и Сангхе.

Второй текст «Mou züdö̈̈n xariulxu sudur orošiboi» [MZ 2] представлен в цифровой библиотеке ойратских рукописей фонда «Тод номын гэрэл». Рукопись (размеры не указаны) состоит из четырех листов, пагинация проставлена тибетскими цифрами в верхнем левом углу. Текст написан черными чернилами кистью, почерк неаккуратный. Количество строк на разных листах разнится: на лл. $1 \mathrm{a}-1 \mathrm{~b}-15$, на лл. $2 \mathrm{a}-2 \mathrm{~b}-16$, на л. $3 a-17$, на последнем л. $3 b-24$. В начале текста после санскритской формулы поклонения Трем Драгоценностям приводит-

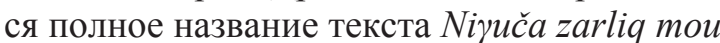
züdü xariluqči bičiq belge ene buyul.

Сопоставительный анализ этих текстов показывает, что они имеют незначительные текстуальные расхождения и, очевидно, являются списками одного сочинения. После молитвы поклонения Трем Драгоценностям (как указано выше, в тексте $\mathrm{MZ}$ 2 ей предшествует аналогичная формула в санскритском произношении) начинается перечисление плохих сновидений и их «отвращение», выстроенное по общей схеме: «... mou zödülüqsen ...-du xarixu boltuүai» (букв. 'пусть то, что приснилось в плохом сне, вернется к ...'). После перечисления людей и животных, сон с участием которых считается плохим, начинается описание образов, которые человек может увидеть

${ }^{1}$ Исследовательница Э. Чиодо пишет, что похожее название («Maүui ǰegüden-i arilyaqu bičig bui» ('Сочинение, очищающее плохие сны')) имеет один из разделов монгольского сочинения «Jegüden-ü tayilburi neretü sudur» ('Сутра под названием «Толкование снов»'), хранящегося в Государственной центральной библиотеке г. Улан-Батора [Chiodo 2000: 217]. Таким образом, можно предположить, что это сочинение изначально входило в состав более крупного сонника, но затем стало функционировать самостоятельно. во сне и которые являются индикаторами того или иного события в будущем. Описание дается по следующему образцу: «... zö̈̈dülbēsü ... belge bui: tö̈̈ni mou dayisun-du xarixu boltuүai〉 ('Если приснилось ..., это знак .... Пусть [последствия] перейдут (букв. 'вернутся') на плохого врага').

Основные разделы ойратских списков «Сутры, отвращающей [влияние] плохих снов»

В рассматриваемых текстах можно условно выделить следующие разделы:

1) плохие сны с людьми:

- если приснился плохой сон с иарем благопожеланий Цакир Бодон-ханом (?), пусть [последствия] перейдут на демона из черных ракшасов;

- если приснился плохой сон с милостынедателями, ханом и ханшей, пусть [последствия] перейдут на трусливого врага;

- если приснился плохой сон с послушником, пусть [последствия] перейдут на демона Тибета (?);

- если приснился плохой сон с ламой-заклинателем, пусть [последствия] перейдут на препятствующих духов.

2) плохие сны с птицами и животными:

- если приснился плохой сон с грифом, пусть [последствия] перейдут на коршуна;

- если приснился плохой сон с кукушкой, пусть [последствия] перейдут на филина (горлииу);

- если приснился плохой сон с попугаем, пусть [последствия] перейдут на серого воробья;

- если приснился плохой сон с бекасом, пусть [последствия] перейдут на cову;

- если приснился плохой сон с журавлем, пусть [последствия] перейдут на чибиса;

- если приснился плохой сон с бельмм львом, пусть [последствия] перейдут на льва желто-коричневой окраски.

3) плохие сны с определенными ситуациями, знаменующими какое-то событие в будущем:

- если приснилось, как падает драгоченный камень чинтамани, [принадлежащий] Гаруде, это знак того, что умрет хороший сановник-министр; 
- если приснилось, как с неба падает синий дракон, это знак того, что умрет служитель бона;

- если приснилось, как в море падает турпан и погибает, это знак того, что умрет послушник;

- если во сне зовет кто-то из умериих, это знак того, что неотвратимо придет посланец Эрлик-хана;

- если во сне сыну отрезают косичку, это знак того, что умрет отец;

- если во сне ломаются золотые сережки, это знак того, что умрет девушка;

- если во сне выпадают зубы, это знак того, что умрет кто-то из близких родственников;

- если во сне ломается навершие шлема, это знак того, что умрет человек ханского происхождения;

- если во сне ломается ушко стрель, это знак того, что умрет кто-то из мужчин;

- если снится, что глаза ослепли, это знак того, что умрет сын нойона;

- если во сне ломается рука, это знак того, что умрет министр;

- если во сне ломается меч, это знак того, что [человек, который видит сон], утратит дух;

- если во сне ломается рукоять копья, это знак того, что [человек, который видит сон], умрет;

- если снится, что падает звезда, это знак того, что умрет богатый человек;

- если снится, что волк задрал овцу, это знак того, что кто-то наложил проклятие;

- если снится, что град побил посевь и цветыл, это знак того, что умрет девушка;

- если снится, что в доме бушует пожар, это знак того, что грядет большая беда;

- если снится, как павлин покидает место проживания [людей], это знак того, что [человек, который видит сон], покинет дом;

- если снится, что собака вдруг начинает лаять, это знак того, что придет злой дух волка.
Оба текста заканчиваются пожеланиями отвращения всех бедствий (связанных с разными отрезками времени) и болезней. В списке MZ 2 отсутствуют три последние фразы списка MZ 1, содержащие пожелания об отвращении неблагоприятного, преумножении добродетелей и блага милостынедателей и долгой жизни для всех. Текст MZ 2 завершается санскритской формулой благопожелания sarva mangalam 'да будет благо'.

\section{Приметы и реалии}

В приведенных приметах интересно отметить отраженные в них реалии социальной организации религиозного и светского общества. Так, в текстах упоминаются служители буддийского и бонского культа, ламы-заклинатели (представители мирской сангхи, которые могут выполнять ритуалы для других) и милостынедатели. Из сословий светского общества упоминаются ханы, нойоны и министры. В разделе, в котором описываются сюжеты сновидений как предзнаменований смерти, основанных на принципе имитативной магии, их смерть связывается с порчей тех или иных объектов: например, сломанное навершие шлема означает смерть хана, сломанная рука смерть министра. Можно предположить, что в сознании монгольских народов шлем был одним из атрибутов власти хана (как руководителя войска) $)^{2}$, поэтому на уровне символики сломанный шлем (в данном случае - навершие) обозначал его смерть. Во втором случае очевидна интерпретация образа министра как «правой руки» властителя. В соннике упоминается еще один знак смерти министра в будущем - упавшая драгоценность чинтамани, который с трудом поддается интерпретации и, возможно, связан с тибетскими реалиями.

Также в текстах идет перечисление птиц и животных, появление которых во сне расценивается как плохой знак. Стоит отметить, что некоторые из упомянутых птиц не считались в монгольской культуре приносящими несчастье, а, напротив, почитались, как кукушка (см. подробно об образе кукушки в культуре монгольских народов: [Бакаева 2009: 38-39]). Возможно, в оппо-

2 См. военный головной убор-шлем хана Кучума как один из символов ханской власти [Маслюженко 2016: 361]. 
зициях кукушка - филин, журавль - чибис, бельй лев - желто-коричневый лев и др. первый компонент имеет положительную коннотацию, а второй, на которого должны перейти негативные последствия, - отрицательную.

Одна примета «Если приснился плохой сон с попугаем, пусть [последствия] перейдут на серого воробья» явно демонстрирует представление о связи мира сновидений с миром мертвых (предков) $)^{3}$ как имеющим противоположную ориентацию: попугай с ярким оперением противопоставляется серому воробью. Т. Г. Борджанова пишет о подобном явлении в калмыцкой культуpe: «У калмыков содержание сновидений истолковывается в основном противоположным образом: если снится сон, что ктото умер, значит, этому человеку дарована длинная жизнь; если во сне видишь свадьбу или пиршество - быть печальному событию» [Борджанова 2007: 118].

Большая часть примет, содержащихся в третьем разделе, говорит о наступлении смерти. Сюжеты, которые человек видит во сне, выступают символическими предзнаменованиями смерти определенных категорий людей: сломанные золотые сережки или град, который бьет цветы, - смерть девушки, сломанное ушко стрелы - смерть мужчины, выпавшие зубы - смерть близкого родственника, отрезанная у сына косичка - смерть отца, падающая звезда смерть богатого человека. Дадим пояснения к некоторым приметам с привлечением этнографических данных:

1. «Если во сне ломаются золотые сережки, это знак того, что умрет девушка». Серьги, являющиеся атрибутами разных половозрастных категорий, в традиционной культуре монгольских народов связаны в первую очередь с силой женщины и имеют защитный характер [Бакаева 2009: 74],

\footnotetext{
${ }^{3}$ Концепция связи мира сновидений с миром мертвых (предков) в тибетской и монгольской культурах подробно рассматривается Е. И. Рабиновичем в его монографии [Рабинович 2013]. Э. Чиодо со ссылкой на Эрдэмта пишет, что монголы приписывали снам большую силу, поскольку верили, что во сне душа покидает тело и, блуждая, встречается с душами предков [Chiodo 2000: 222].
}

поэтому сломанные серьги как разрушение защиты жизни символизируют смерть девушки.

2. «Если во сне сыну отрезают косичку, это знак того, что умрет отеия. Волосы во многих традиционных культурах считаются местопребыванием души, поэтому их отрезание является символом смерти.

3. «Если во сне выпадают зубы, это знак того, что умрет кто-то из близких родственников». Выпадение зубов во сне как знак скорой смерти является одним из универсальных образов во всех мировых культурах. О калмыцкой примете пишет У. Душан: «Самым дурным считается сон, где фигурирует выпадение зубов. Если человеку приснится, что у него выпали коренные зубы, то это значит, что непременно должен умереть кто-нибудь из младших членов семьи. Если же выпали последние зубы (резцы), то должен умереть кто-нибудь из родителей» [Душан 2016: 253]. Эта примета сохраняется и у современных бурят: по материалам Е. И. Рабиновича, одним из образов сновидений, однозначно маркируемых как неблагоприятные, являются выпавшие зубы [Рабинович 2013: 167].

4. «Если во сне ломается ушко стрелы, это знак того, что умрет кто-то из мужчин». Стрела в мировосприятии монгольских народов является символом мужского начала [Бакаева 2003: 116]. Стоит отметить, что в этом соннике встречаются упоминания и других предметов военного вооружения - шлема (соотносимого на уровне магии подобия с человеком ханского происхождения), меча (соотносимого с бодростью духа (жизненной силой?) человека) и копья (соотносимого с жизнью человека).

5. «Если снится, что падает звезда, это знак того, что умрет богатый человек». Калмыки считали, что души некоторых людей после смерти превращаются в звезды [Бакаева 2003: 68]. 


\section{Функции «Сутры, отвращающей [влияние] плохих снов»}

Из содержания сочинения видно, что оно выполняло две функции: выступало руководством по толкованию снов и отвращало вредоносные влияния плохих снов путем его начитывания. Система толкования снов как часть общей мантической практики (монг. tölgö $)$ монгольских народов имеет древнее происхождение: первое упоминание этой практики в письменном тексте встречается в «Сокровенном сказании монголов» (§ 63, в котором Дай-Сэцэн говорит о своем пророческом сне о Тэмуджине). С широким распространением тибетского буддизма практика снотолкования вошла в состав буддийской обрядности, смешавшись с тибетской традицией. Е. И. Рабинович в ходе анализа монгольской культурной модели сновидений устанавливает существование северо-буддийской культуры сна и сновидений, «в которой тибетская форма буддизма является главным структурообразующим элементом», и отмечается сильное влияние центральноазиатского шаманизма [Рабинович 2013: 170].

Что касается ритуалов нейтрализации плохих сновидений, анализ этнографических данных позволяет говорить о том, что, если раньше эти ритуалы в некоторых традициях были связаны с добуддийскими верованиями ${ }^{5}$, то в настоящее время они отно-

${ }^{4}$ А. Рона-Таш относит это слово к заимствованиям из уйгурского, причем уйгурское слово tölüg (tölük) он возводит к основе tül 'сон' [RónaTas 1972: 231]. Сны служили одним из инструментов для гадания, наряду с монетами, красной нитью, лопаткой, стрелой и пр. [Róna-Tas 1972: 234]. Исследователь считает, что в монгольском языке tölgö утратило второе значение 'сон', для обозначения которого стало использоваться только јеgüdün [Róna-Tas 1972: 235].

${ }^{5}$ А. Рона-Таш со ссылкой на венгерского исследователя Г. Месароша, посвятившего книгу ранним религиозным верованиям чувашей, пишет о том, что в их традиции специальный толкователь снов объяснял значение сна через свой сон после того, как он помещал вещь человека, обратившегося к нему, под подушку [Róna-Tas 1972: 235]. У. Душан пишет о калмыцких знахарях, которые, уверяя, что во время сна к ним прилетают святые духи и могут ответить на любые вопросы, оставляли обращавшихся к ним людей ночевать рядом [Душан 2016: 254]. сятся к буддийской обрядности и включают только чтение определенных тибетских текстов или присутствие на молебне, на котором зачитываются эти тексты. Э. Чиодо пишет о том, что прежде хорчинские монголы для толкования снов обращались к гадателю (монг. üjеgс̌i). Если плохой сон был наслан врагом, шаман проводил особый обряд. Современные же хорчины приглашают ламу для чтения специального текста и проведения огненного подношения [Chiodo 2000: 222]. Т. Г. Борджанова (Басангова) упоминает, что в калмыцкой традиции в случае плохого сновидения ламы совершали обряд уничтожения предзнаменований плохого сна зүүд хәрүүлх [Борджанова 2007: 118]. Возможно, этот обряд в начале $\mathrm{XX}$ в. был записан У. Душаном ${ }^{6}$ : «Приглашенные гелюнги читают молитвы, приготовляют фигурки из теста, заставляют видевшего сон держать во рту солому или палочку в то время, когда читается молитва. По окончании молитвы видевший сон должен три раза плюнуть на солому через отверстие над решеткой у самой двери (тотхо). После этого солому выбрасывают. Человек, видевший нехороший сон, немедленно после пробуждения должен три раза плюнуть, заклиная, чтобы то, что он видел во сне, не случилось» [Душан 2016: 253].

Можно предположить, что в число упоминаемых Э. Чиодо и У. Душаном молитвенных текстов, начитываемых ламами при проведении обряда нейтрализации дурного сновидения, входила и «Сутра, отвращающая [влияние] плохих снов». Очевидно, что повторяющийся в текстах лейтмотив «Пусть последствия перейдут на плохого врага!» маркировал совершение какого-то ритуального действия.

Е. И. Рабинович приводит интересные сведения о способах «отвращения» плохих снов в современной буддийской традиции Монголии и Бурятии. Нейтрализации требуют не все сны, как пишет автор, а лишь наделенные прогностической функцией, которые, по сообщениям некоторых информантов, могут присниться весной и осенью ранним утром до восхода солнца [Рабинович 2013: 162]. В этих целях монгольские ламы рекомендуют проводить ритуалы Бе-

\footnotetext{
${ }^{6}$ Автор описывает обряд без указания названия, проводившийся в случае, если человек увидел плохой сон.
} 
лозонтичной или Зеленой Тары и ритуал туй (омовение зеркала) [Рабинович 2013: 157].

Бурятская буддийская традиция предписывает в таких случаях посещение определенных молебнов (хуралов) и выполнение алгоритма действий, включающих написание своего имени на листе бумаги, чтобы оно было прочитано во время хурала, обращение к божествам с просьбой о помощи, рецитирование мантры Зеленой Тары и призывание двадцати одной формы Тары [Paбинович 2013: 163]. Из хуралов, связанных с устранением последствий сновидений, можно назвать следующие: Табан харюулга (букв. 'Пять отводов'), Доржо Жодбо («Алмазная сутра»), Санжид монлам («Бхадрачарья»), Дэвжид сэржэм («Подношение золотого напитка серкем восьми классам») [Рабинович 2013: 163-164]. Собранные Е. И. Рабиновичем данные показывают угасание традиции использования монголоязычных и тибетоязычных сонников в настоящее время [Рабинович 2013: 168].

Происхождение «Сутры, отвращаюшей [влияние] плохих снов»

В рамках данного исследования представляется интересным также затронуть проблему происхождения «Сутры, отвращающей [влияние] плохих снов». В поисках оригинала можно обратиться к тибетской традиции. Среди сочинений, представленных в цифровой библиотеке тибетских текстов Tibetan Buddhist Resource Center, возможным оригиналом, судя по названию, может быть текст «Rmi lam ngan pa bzlog thabs bzhugs so» ('Способ отвращения плохих снов') 7 . Однако анализ текста показывает, что по содержанию он отличается от рассматриваемых ойратских рукописей: в нем содержатся буддийские наставления по визуализации в ситуациях, когда человеку снится плохой сон, описание образов сновидений отсутствует. Поскольку это сочинение небольшого объема, мы считаем возможным привести его текст полностью:

'Что касается способа отвращения плохих снов, [нужно делать следующее]. Если ночью приснился плохой сон, сразу после

${ }^{7}$ Rmi lam ngan pa bzlog thabs (je) [электронный ресурс] // Buddhist Digital Resource Center. URL: https://www.tbrc.org/\#library_work ViewByOutline-O01DG1049095439\%7CW23922 (дата обращения: 22.12.2019). пробуждения нужно поставить торма, в пространстве перед собой породить (визуализировать) [своего] Защитника с окружением. [Затем] пригласите джнянасаттв (существ мудрости), которые растворяются [в представляемых божествах]. Они становятся нераздельными с Учителем-защитником - так с усилием возносите молитвы и восхваления. Затем начитывайте как можно больше раз коренную мантру сарва бигхнан щзатрум марая и пр. и представляйте при этом, как от лика Учителя к вашему лицу, от пупка (центра) Учителя к вашему [тянется] цепочка гневной мантры, и она излучает сияние, подобное языкам пламени. Затем визуализируйте те образы, которые вы увидели в плохом сне, и снова и снова представляйте, как они сгорают без остатка в всполохах пламени, подобно птичьему перу, объятому огнем. После этого, благословляя торма, представьте, что вы помещаете все, что приснилось, в торма как в сосуд, и благословите его' mgon po la brten nas rmi lam ngan pa bzlog pa'i thabs la / mtshan mo rmi lam ngan pa rmis na / gnyid sad ma thag mdun du gtor ma bshams / mdun gyi nam mkha' mgon po 'khor bcas bskyed / de la ye shes pa spyan drangs la bstim pas / bla ma mgon po dbyer med la / ces gsol ba drag tu btab / bstod par bya / de nas rtsa sngags la sa+rba bi+ghnan sha trum ma rā ya'i spel tshig dang bcas pa'i bzlas pa ci mang byas te / de nas rang gi zhal nas mgon po'i zhal dang / mgon po'i lte ba nas rang gi lte bar 'khro ba'i sngags kyi phreng ba las 'od zer me 'od lta bu 'phros pas / rmi lam ngan pa ji ltar rmis pa'i rnam pa de ltar bsgom pas / de rnams bya sgro mes tshig pa ltar lhag ma med par cham cham bsregs par bsam pa yang yang bya / de nas gtor ma byin rlabs byed na / rmi lam ngan pa ji ltar rmis pa de yang gtor snod du bcug par mos tel byin gyis rlabs pas /'od dmar shig ge bar song bar bsgom ste / mgon po 'khor bcas kyi zhal nas / 'od kyi sbu gu byung ba gtor ma zug ste / rmi lam ngan pa dengs te sib sib gsol bar bsam / de nas 'phrin las kyang bcol lo / rmi lam shin tu ngan na nyin ma 'od gtor ma bcas la gsol ba btab / byang stongs sam gtor ma mi 'dzem pa'i sar rang gi mdun du thod par dmigs pa bskyed la 'bul gsungs / 'dzoms pa'i 'dzin gtor sogs yod kyang gtor chung bshams par bya'o // $i+$ thi $/ /$.

В другом тибетском сочинении о толковании сновидений «Rmi lam bzang ngan brda rtags kyi rim pa» ('Категории знаков 
хороших и плохих сновидений') 8 приводится перечень образов неблагоприятных сновидений, который отличается от тех, что содержатся в ойратских списках «Сутры, устраняющей влияние плохих снов»:

'[Плохо, если] снятся сумерки, высохшие деревья, побитый градом урожай, закат солнца, исчезновение луны или затмение, разрушенный причал, несвобода от [опасностей] перевалов, рек и ущелий, бег вниз, взятие под стражу, ношение плохой одежды, ухудшение здоровья, отрезание, сжигание или выпадение волос и бороды, порча тех или иных атрибутов, стрел, луков, мечей и др. [Плохо, если снится, как тебя] преследуют град или волны, если падаешь в пропасть, лежишь в плохой одежде; если у тебя идет кровь, тело натерто или облачено во что-то плохое; если тонешь в грязном болоте или твое тело поедают насекомые; если ты ешь плохую пищу, тебя преследуют птицы или хищники, тебя застает землетрясение; если снится, что рушится крепость, ты теряешься в пути или окружен умершими, которые ведут тебя; если ты страдаешь от какого-либо оружия: стрелы, копья и т. д., если у тебя просят еду и питье прокаженный или слепой; если тебя преследуют долги; если тебя ведет куда-то без твоей воли человек, который тебе не нравится; если тебя уносит сильным ветром; если ты едешь верхом на черном осле или дикой лошади, не управляя ею; если ты бесцельно бродишь в одиночестве. Если ты видишь такой сон, в жизни возникнут препятствия, достижения сиддхи придут в упадок, будут копиться долги, враги нашлют проклятья, начнутся болезни, злословие, задуманное не будет исполняться, возникнут конфликты и множество кармических омрачений, появятся знаки будущего неблагого рождения' mun pa sros pa / rtsi shing nags tshal skam pa / lo 'bras sad ser gyis bcom pa / nyi zla nub pa dang gzas zin pa / gru zam zhig pa / la chu 'phrang gsum las ma thar ba / thur du rgyug pa / btson du bzung ba dang / khri mon dong du bskyur ba dang (?) / rang gi chas gos ngan pa / lus rgud pa / skra dang kha spu bregs sam tshig pa dang byi ba / lag cha phyag mtshan dang mda' gzhu gri sogs chag pa

\footnotetext{
${ }^{8} \mathrm{Rmi}$ lam bzang ngan brda rtags kyi rim pa/ (ya) [электронный ресурс] // Buddhist Digital Resource Center. URL: https://www.tbrc.org/\#library_work ViewByOutline-O23445C2O0160\%7CW23445 (дата обращения: 22.12.2019).
}

la sogs lnga ma las log cing thog ser dang rbab kyis ded pa / g.yang la lhung ba / gos ngan gon nas nyal ba / lus la khrag ngan la sogs pa dang / rdzas ngan gyis byugs shing gos pa / mi gtsang ba'i 'dam du byings pa / lus la 'bu sbrang la sogs pas bza' ba / zas ngan zos pa / bya gcan gyis ded pa / sa rdib kyis non pa / sa mkhar zhig pa dang / gas pa dang / lam stor ba / gshin po'i tshogs kyis bskor ba dang khrid pa / lus drwa ba'i nang du tshud pa dang (?) / mda' mdung la sogs pa mtshon chas gzir ba / mdze pho dang long sprang la sogs pas bza' btung bslang zhing bsnyad pa dang / bu lon ded pa / mi dga' ba'i mis rang dbang med par khrid pa / rlung dmar 'tshubs nas ded pa / bong bu nag po la zhon pa / rta rgod la zhon nas dbang med du khrid pa / ram rug spang g.yeng la sogs mi kha'i rdzas la spyod pa (?) / rang nyid gcig pus rgyus med du 'khyams pa la sogs mdor na / tshe la bar chad 'byung ba dang / dngos grub nyams pa dang / lan chags 'du ba dang / pha rol gyi byad zug pa dang / nad 'jug pa dang / mi kha 'du ba dang / bsam pa'i don mi 'grub pa dang / kha smras gleng gzhi gyod thug 'byung ba dang / las kyi sgrib pa che ba dang / ngan song du 'gro ba la sogs pa'i ltas mang po 'byung.

Обширная цитата из тибетского сонника показывает, что образы сновидений, интерпретируемые в тибетском и ойратских текстах как неблагоприятные, различаются и имеют мало схожего: общими являются лишь универсальные во многих культурах образы отрезания волос и встречи с умершими 9 . Это может свидетельствовать о том, что во время утверждения тибетского буддизма в монгольской культуре уже существовала сложившаяся система снотолкования и методов нейтрализации плохих снов, которая, получив буддийское обрамление, вошла в состав обрядности, сохранив при этом традиционные для монгольских народов образы благоприятных и неблагоприятных сновидений. Анализ ойратских списков «Сутры, отвращающей [влияние] плохих снов» не позволяет однозначно решить проблему ее происхождения, относится ли она к переводам с тибетского или представляет собой образец монголоязычной письменной традиции.

\footnotetext{
${ }^{9}$ Интересно отметить, что в тибетском тексте присутствуют образы сломанного оружия (стрел, копий), которые встречаются и в ойратских списках «Сутры, отвращающей [влияние] плохих снов».
} 
Настоящее исследование имеет несколько ограничений: письменные памятники, несомненно, отражают лишь небольшую часть мировосприятия монгольских народов; кроме того, необходимы ввод в научный оборот и анализ других сочинений тибето-монгольской литературы по данной тематике.

\section{Заключение}

Проведенное исследование позволяет сделать следующие выводы: ойратские рукописи «Сутры, отвращающей [влияние] плохих снов» из НА КалмНЦ РАН и цифровой библиотеки ойратских рукописей фонда «Тод номын гэрэл» представляют собой списки популярного сонника, широко представленного и на классическом монгольском, самые ранние образцы которого относятся к первой половине XVII в. Возможно, эта сутра изначально входила в состав более крупного сочинения «Сутра под назва-

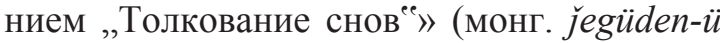
tayilburi neretü sudur), однако постепенно стала функционировать самостоятельно.

\section{Источники}

MZ 1 - Молитва от дурных сновидений // Научный архив Калмыцкого научного центра РАН. Ф. 15. ОП. 1. Ед. хр. 413.

MZ 2 - Mou zöüden xarilixui sudur orošiboi (' $\mathrm{Cy}$ тра, [отвращающая] влияние плохих снов’) [электронный ресурс] // Digital Library for International Research Archive, Item \#11410. URL: http://www.dlir.org/archive/items/ show/11410 (дата обращения: 23.12.2019)

\section{Литература}

Бакаева 2003 - Бакаева Э. П. Добуддийские верования калмыков. Элиста: АПП «Джангар», 2003. $358 \mathrm{c.}$.

Бакаева 2009 - Бакаева Э. П. Сакральные коды культуры калмыков. Элиста: ИКИАТ, 2009. $159 \mathrm{c}$.

Борджанова 2007 - Борджанова Т. Г. Обрядовая поэзия калмыков (система жанров, поэтика). Элиста: Калм. кн. изд-во, 2007. 592 с.

Галданова 1987 - Галданова Г. Р. Доламаистские верования бурят. Новосибирск: Наука, $1987.115 \mathrm{c}$.

Душан 2016 - Душан У. Избранные труды / сост. В. В. Батыров, Т. И. Шараева. Элиста: КИГИ РАН, 2016. 376 с

Маслюженко 2016 - Маслюженко Д. Н. Символы власти в источниках по истории Тюменского ханства // Золотоордынское обо-
Анализ содержания ойратских рукописей позволяет выделить в них три раздела: плохие сны с людьми; плохие сны с птицами и животными и плохие сны с определенными ситуациями, предвещающими смерть. Некоторые из рассмотренных примет сохраняют свое бытование в современной культуре монгольских народов. Большая часть из них основана на принципе имитативной магии, а также восприятии единого пространства сновидений и мира предков как мира с противоположной ориентацией. Сопоставление ойратских списков сонника с тибетскими текстами, имеющими аналогичное название, показало отсутствие сходства в системе образов неблагоприятных сновидений и методах их нейтрализации. Тем не менее проблема определения оригинального текста не может быть решена однозначно. Подобные исследования образцов монголоязычного литературного наследия в числе прочих задач позволят описать отраженные в них аспекты традиционной картины мира монгольских народов.

зрение. 2016. Т. 4. № 2. С. 360-368.

Орлова 2002 - Орлова К. В. Описание монгольских рукописей и ксилографов, хранящихся в фондах Калмыкии // Бюллетень Общества востоковедов. Вып. 5. М.: Ин-т востоковедения РАН, КИГИ РАН, 2002. 85 с.

Рабинович 2013 - Рабинович Е. И. Сны Пробужденных: сон и сновидения в культуре, религии, политике Тибета. Екатеринбург: Гуманит. ун-т, 2013. $200 \mathrm{c}$.

Сазыкин 1988 - Сазыкин А. Г. Каталог монгольских рукописей и ксилографов Института востоковедения Академии наук СССР. Т. І. М.: Наука; ГРВЛ, 1988. 506 с.

Сазыкин 2001 - Сазыкин А. Г. Каталог монгольских рукописей и ксилографов Института востоковедения Российской академии наук. Т. II. М.: Вост. лит., 2001. 415 с.

Цендина 2019 - Цендина А. Д. Монгольское сочинение о гадании по приметам из собрания Рукописного фонда ИВР РАН // Oriental Studies. 2019. № 2. С. 263-278.

Шараева 2011 - Шараева Т. И. Обряды жизненного цикла калмыков (XIX в. - нач. XX в.). Элиста: НПП «Джангар», 2011. 223 с.

Chiodo 2000 - Chiodo E. The Mongolian Manuscripts on Birch Bark from Xarbuxyn Balgas in the Collection of the Mongolian Academy of Sciences. Part 1. Wiesbaden: Harrassowitz Verlag, 2000. 305 p. 
Humphrey 1976 - Humphrey C. Omens and their Explanation among the Buryat // European Journal of Sociology. XVII. 1976. No. 1. Pp. 21-38.

\section{Sources}

[Prayer Preventing Bad Dreams]. At: Kalmyk Scientific Center of the RAS, Scientific Archive. Coll. 15. Cat. 1. Item no. 413. (In Oir.)

[Mou zö̈̈den xarilixui sudur orošiboi: Sūtra Averting (Effects of) Bad Dreams]. At: Digital Library for International Research, Tod Nomin Gerel Collection. Item no. 11410. Available at: http://www.dlir.org/archive/items/show/11410 (accessed: December 23, 2019). (In Oir.)

\section{References}

Bakaeva E. P. [Kalmyk Pre-Buddhist Beliefs]. Elista: Dzhangar, 2003. 358 p. (In Russ.)

Bakaeva E. P. [Sacred Codes of Kalmyk Culture]. Elista: Institute for Comprehensive Research of Arid Territories, 2009. 159 p. (In Russ.)

Bordzhanova T. G. [Kalmyk Ritual Poetry: Genre System, Poetics]. Elista: Kalmyk Book Publ., 2007. 592 p. (In Russ.)

Chiodo E. The Mongolian Manuscripts on Birch Bark from Xarbuxyn Balgas in the Collection of the Mongolian Academy of Sciences. Part 1. Wiesbaden: Harrassowitz Verlag, 2000. 305 p. (In Eng.)

Dushan U. [Selected Works]. V. V. Batyrov, T. I. Sharaeva (comps.). Elista: Kalmyk Humanities Research Institute of RAS, 2016. 376 p. (In Russ.)

Galdanova G. R. [Buryat Pre-Lamaist Beliefs]. Novosibirsk: Nauka, 1987. 115 p. (In Russ.)

Humphrey C. Omens and their explanation among the Buryat. European Journal of Sociology. 1976. Vol. XVII. No. 1. Pp. 21-38. (In Eng.)
Róna-Tas 1972 - Róna-Tas A. Dream, Magic Power and Divination in the Altaic World // Acta Orientalia Academiae Scientiarum Hungaricae. T. XXV. 1972. Pp. 227-236.

Maslyuzhenko D. N. Symbols of power in the sources on the history of Tyumen Khanate. Golden Horde Review. 2016. Vol. 4. No. 2. Pp. 360-368. (In Russ.)

Orlova K. V. [Description of Kalmykia-Based Mongolian Manuscripts and Xylographs]. Ser. 'Newsletter'. Russian Society of Orientalists. Vol. 5. Moscow: Institute of Oriental Studies (RAS), Kalmyk Humanities Research Institute of RAS, 2002. 85 p. (In Russ.)

Rabinovich E. I. [Dreams of the Awakened: Sleep and Dreams in Tibetan Culture, Religion, and Policy]. Yekaterinburg: Ural Institute of Humanities, 2013. 200 p. (In Russ.)

Róna-Tas A. Dream, magic power and divination in the Altaic world. Acta Orientalia Academiae Scientiarum Hungaricae. 1972. Vol. XXV. Pp. 227-236. (In Eng.)

Sazykin A. G. [Institute of Oriental Studies, Russian Academy of Sciences: Catalogue of Mongolian Manuscripts and Xylographs]. Vol. II. Moscow: Vostochnaya Literatura, 2001. 415 p. (In Russ.)

Sazykin A. G. [Institute of Oriental Studies, USSR Academy of Sciences: Catalogue of Mongolian Manuscripts and Xylographs]. Vol. I. Moscow: Nauka; GRVL, 1988. 506 p. (In Russ.)

Sharaeva T. I. [Kalmyk Life-Cycle Rituals: $19^{\text {th }}-$ Early $20^{\text {th }}$ Centuries]. Elista: Dzhangar, 2011. 223 p. (In Russ.)

Tsendina A. D. A Mongolian manuscript on divination by omens from the collection of the Manuscript Fund of the Institute of Oriental Manuscripts of the RAS. Oriental Studies. 2019. No. 2. Pp. 263-278. (In Russ.) DOI: 10.22162/2619-0990-2019-42-2-263-278 


\section{Транслитерация и перевод ойратской рукописи

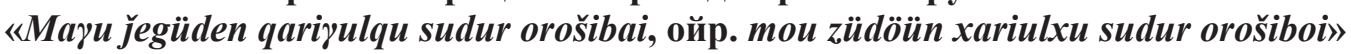

[НА КалмНЦ РАН. Ф. 15. Оп. 1. Ед. хр. 413] $]^{10}$

\section{Молитва от дурных снов}

[1] blama-du mürgümüi:

burxan-du mürgümüi:

nom-du mürgümüi:

bursang xuvaraq-tu mürgümüi:

xamuq mou zöüdün zedger xarixu boltuүai:
Поклоняюсь Учителю.

Поклоняюсь Будде.

Поклоняюсь Дхарме.

Поклоняюсь Сангхе.

Пусть все вредоносные [влияния] плохих снов будут отвращены!

irö̈̈liyin xan čakir bodon xāni mou Если приснился плохой сон с царем благопожеланий zö̈̈dülüqsen xara raqša čidkür-tü xarixu Цакир Бодон-ханом, пусть [последствия] перейдут на bolturai: демона из черных ракшасов!

öqligöyin ezeni xan xatun mou zö̈̈dülüqsen Если приснился плохой сон с милостынедателями, bekeyē dayisan-du xarixu boltuүai: ханом и ханшей, пусть [последствия] перейдут на трусливого врага!

bandi kümüni mou zöüdülüqsen töbödöin Если приснился плохой сон с буддийским ламой,

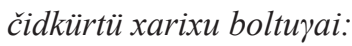
пусть [последствия] перейдут на демона Тибета!

sangrasba11 kümüni mou zö̈̈dülüqsen ada Если приснился плохой сон с ламой-заклинателем, todxor-tu xarixu bolturai: пусть [последствия] перейдут на препятствующих духов!

xaǰir šobouni mou zö̈̈ülüqsen elei šoboun- Если приснился плохой сон с грифом, пусть du xarixu boltuүai: [последствия] перейдут на коршуна!

toti šobouni mou zöüdülüqsen boro bolǰimar Если приснился плохой сон с попугаем, пусть

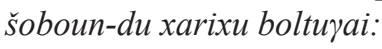
[последствия] перейдут на серого воробья!

kekili $^{12}$ šobouni mou zöüdülüqsen ouli šoboun- Если приснился плохой сон с бекасом, пусть du xarixu boltuүai: [последствия] перейдут на сову!

kököge šobouni mou zö̈̈ülüqsen kelegi Если приснился плохой сон с кукушкой, пусть [=delekei] kötögö šoboun-du xarixu boltuүai: [последствия] перейдут на горлицу!

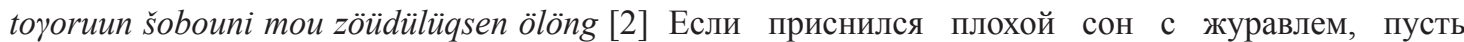
todxor [=xudxur] šoboun-du xarixu bolturai: [последствия] перейдут на чибиса!

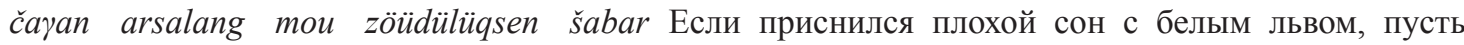
arsalang-du xarixu boltuүai: [последствия] перейдут на льва желто-коричневой ${ }^{13}$ окраски!

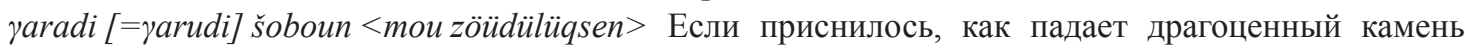
čindamani-ēče unan zö̈̈dülbesü töröyin sayin чинтамани, [принадлежащий] Гаруде ${ }^{15}$, это знак tüšimel ükükü belge bui: töüni mou dayisan- того, что умрет хороший сановник-министр. Пусть du xarixu boltuүai ${ }^{14}$ : последствия перейдут на плохого врага!

kükü klu oqtoryui-ēče unan zö̈dülbesü bumba Если приснилось, как с неба падает синий дракон kümün ükükü belge bui töüni mou dayisun-du (нага), это знак того, что умрет жрец бонпо. Пусть xarixu bolturai

10 В транслитерации используются следующие условные знаки: в фигурных скобках \{\} приводятся межстрочные вставки в тексте, со знаком равенства в скобках [=] — классическое написание слова, вычеркнутые в транслитерации, заключены в угловые скобки $<>$.

${ }^{11}$ От тиб. sngags pa 'заклинатель'.

12 Э. Чиодо приводит написание qakili ‘бекас’ [Chiodo 2000: 218].

${ }^{13}$ Букв. 'глиняного'.

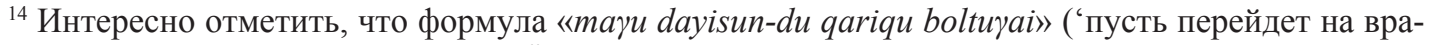
га’) встречается в другом сочинении «Öljei-tü qutuүtu tarni» [Chiodo 2000: 223].

15 В бурятской иконографической традиции сохранился образ Гаруды, на макушке которого расположена драгоценность чинтамани (см.: Шабала Гаруда [электронный ресурс] // Буддийская живопись Бурятии. URL: http://online.stack.net/ alex/19s.htm (дата обращения: 22.12.2019)). 
anggir šoboun dalai-du unaji ükün zö̈̈dülbēsü Если приснилось, как в море падает турпан и погибает, bandi kümün ükükü belge bui töüni mou это знак того, что умрет буддийский лама. Пусть dayisun-du xarixu boltuүai: последствия перейдут на плохого врага!

üküqsen kümün doudan zöüdülbēsü Erliq xāni Если во сне зовет кто-то из умерших, это знак того, elči tesel [=tengsel] ügei irekü belge bui tö̈̈ni что неотвратимо придет посланец Эрлик-хана. Пусть mou dayisun-du xarixu boltuүai: последствия перейдут на плохого врага!

köbö̈̈ni gejige utolun zö̈̈dülbēsü ečige Если во сне сыну отрезают косичку, это знак того, что ükükü belge bui: tö̈̈ni mou dayisun-du xarixu умрет отец. Пусть последствия перейдут на плохого bolturai: врага!

altan [3] seyikü xuүaran zöüdülbēsü okin Если во сне ломаются золотые сережки, это знак того, kümün ükükü belge bui töüni mou dayisun- что умрет девушка. Пусть последствия перейдут на $\{d u\}$ xarixu bolturai: плохого врага!

sumuni ono xayarin zö̈̈dülbēsü eren dunda Если во сне ломается ушко стрелы, это знак того, что kümün ükükü belge bui töüni mou dayisun-du умрет кто-то из мужчин. Пусть последствия перейдут xarixu bolturai: на плохого врага!

nidün soxoron zöüdülbēsü noyon köböun Если снится, что глаза ослепли, это знак того, что ükükü belge bui töüni mou dayisan-du xarixu умрет сын нойона. Пусть последствия перейдут на bolturai: плохого врага!

südün unan zö̈̈lülbēsü axa dou uruq ükükü Если во сне выпадают зубы, это знак того, что умрет belge bui tö̈̈ni mou dayisadu xarixu boltuүai: кто-то из близких родственников. Пусть последствия перейдут на плохого врага!

yar xuүuran zöüdülbesü sād tüšimel ükükü Если во сне ломается рука, это знак того, что умрет belge bui töüni mou dayisun-du xarixu министр. Пусть последствия перейдут на плохого bolturai: врага!

ildu xuүaran zö̈̈dülbēsü zürke aldaxu belge Если во сне ломается меч, это знак того, что [человек, bui: töüni mou dayisun-du xarixu boltuүai: который видит сон], утратит дух. Пусть последствия перейдут на плохого врага!

juidān eši xuүaran zöüdülbēsü yol tasurxu belge Если во сне ломается рукоять копья, это знак того, bui töüni mou dayisun-du xarixu boltuүai: что [человек, который видит сон], умрет. Пусть последствия перейдут на плохого врага!

odun unan zöüdülbēsü bayan kümün [3] Если снится, что падает звезда, это знак того, что ükükü belge bui tö̈̈ni mou dayisun-du xarixu умрет богатый человек. Пусть последствия перейдут boltuүai: на плохого врага!

čino xoni alan zö̈̈dülbēsü xarāl kürkü belge Если снится, что волк задрал овцу, это знак того, bui töüni mou dayisudu xarixu boltuүai: что кто-то наложил проклятие. Пусть последствия перейдут на плохого врага!

öbösün čečeq-tü mönder buun zöüdülbēsü eте Если снится, что град побил посевы и цветы, это знак kü̈̈ken ükükü belge bui: tö̈̈ni mou dayisun-du того, что умрет девушка. Пусть последствия перейдут xarixu boltujai: на плохого врага!

gertü yeke tüyimör aldan zöüdülbēsü yeke yai Если снится, что в доме бушует пожар, это знак того, yamšiq bolxu belge bui töüni mou dayisun-du что грядет большая беда. Пусть последствия перейдут xarixu boltuүai: на плохого врага!

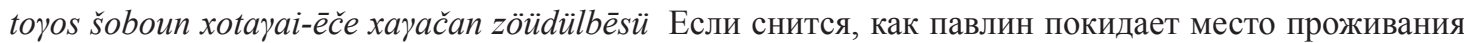

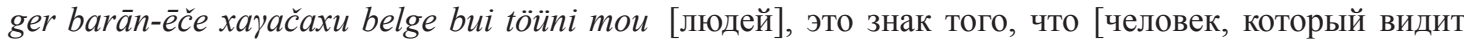
dayisun-du xarixu bolturai. сон], покинет дом. Пусть последствия перейдут на плохого врага!

genete noxoi uli\{xuin zö̈̈delbesü\} tenggeriyin Если снится, что собака вдруг начинает лаять, это знак noxoi čidkür irekü belge bui töüni mou того, что придет злой дух волка ${ }^{16}$. Пусть последствия dayisun-du xarixu boltuyai: перейдут на плохого врага!

dörbön zoun nayiman ebečin činaqši xarixu Пусть четыреста восемь болезней отступят! bolturai:

${ }^{16}$ Букв. 'небесного пса'. Интересно отметить, что в хакасских приметах о снах волк считается предвестником злого духа [Аникеева 2019: 25]. Вероятно, в данном случае подразумевается несчастье от разорения стада. 


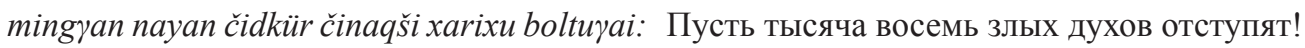

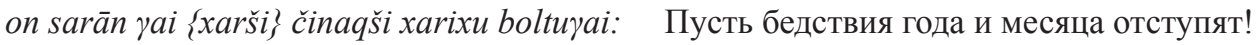
ödör šöniyin rai \{xarši $\}$ činaqši xarixu Пусть бедствия дня и ночи отступят! boltuүai:

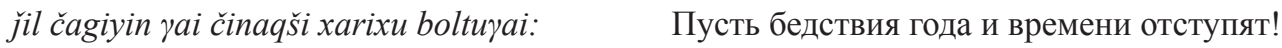

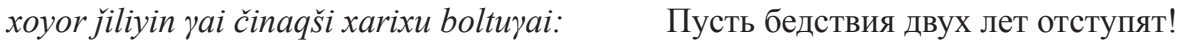
yai zobolong kigēd ada todxor kilinče bügüdör Пусть все бедствия, страдания, препятствия и činaqši xarixu boltuүai:

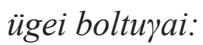
прегрешения отступят!

xarixu boltuүai:

Пусть исчезнут!

öqligöyin ezen noyon xatuni \{bideni\} buyan Пусть преумножатся добродетель и счастье kišiq nemekü bolturai: милостынедателей, князей и их супруг и наши! amin nasun bidandu urtu bolxu bolturai:: Пусть наша жизнь станет долгой!

Приложение 2.

Факсимиле ойратской рукописи «Maүu јеgüden qarizulqu sudur orošibai, ойр. тои züdö̈̈n xariulxu sudur orošiboi» [НА КалмНЦ РАН. Ф. 15. Оп. 1. Ед. хр. 413]

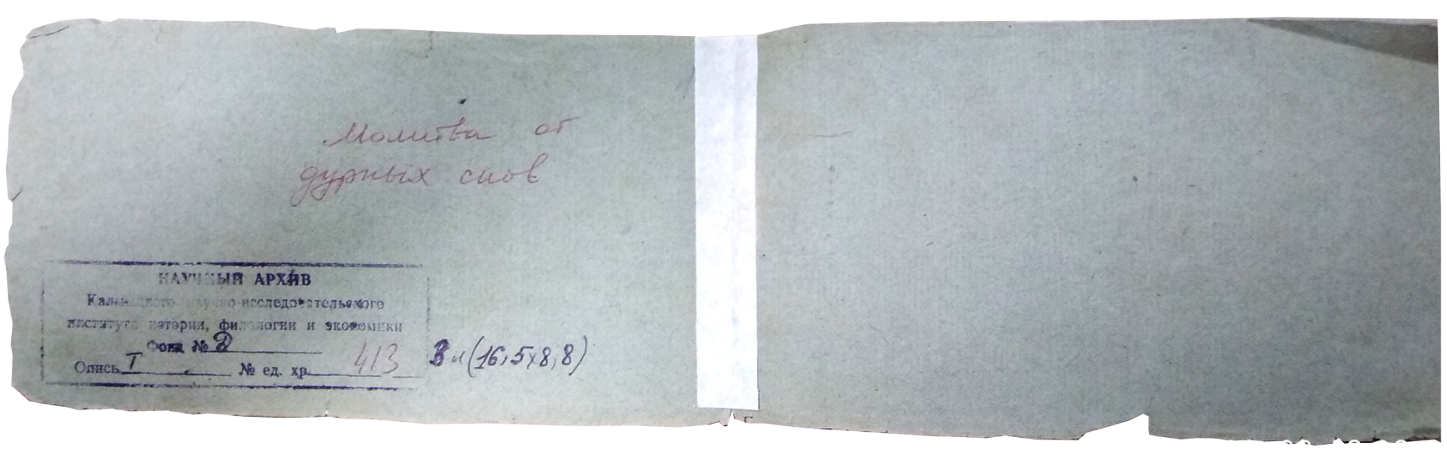



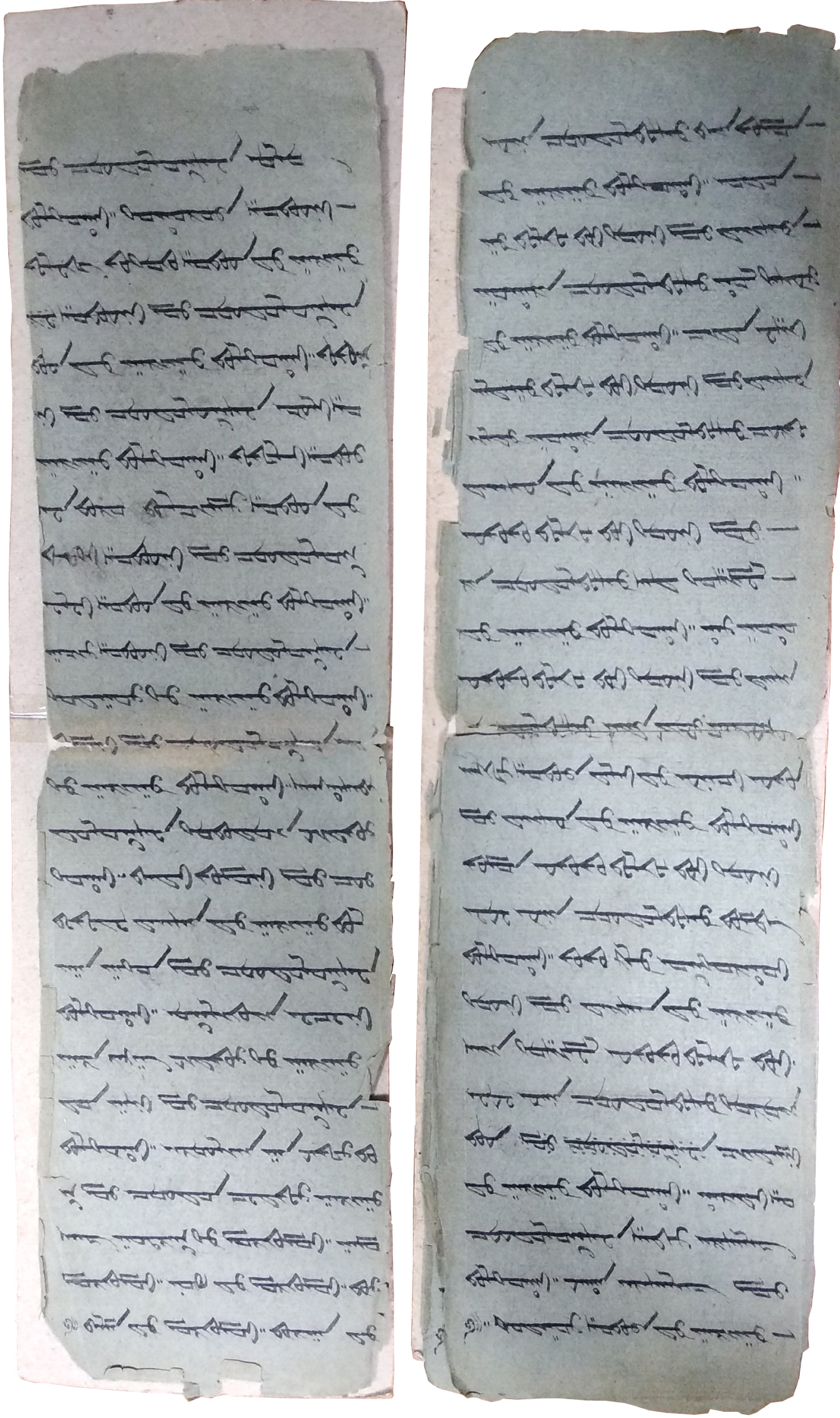


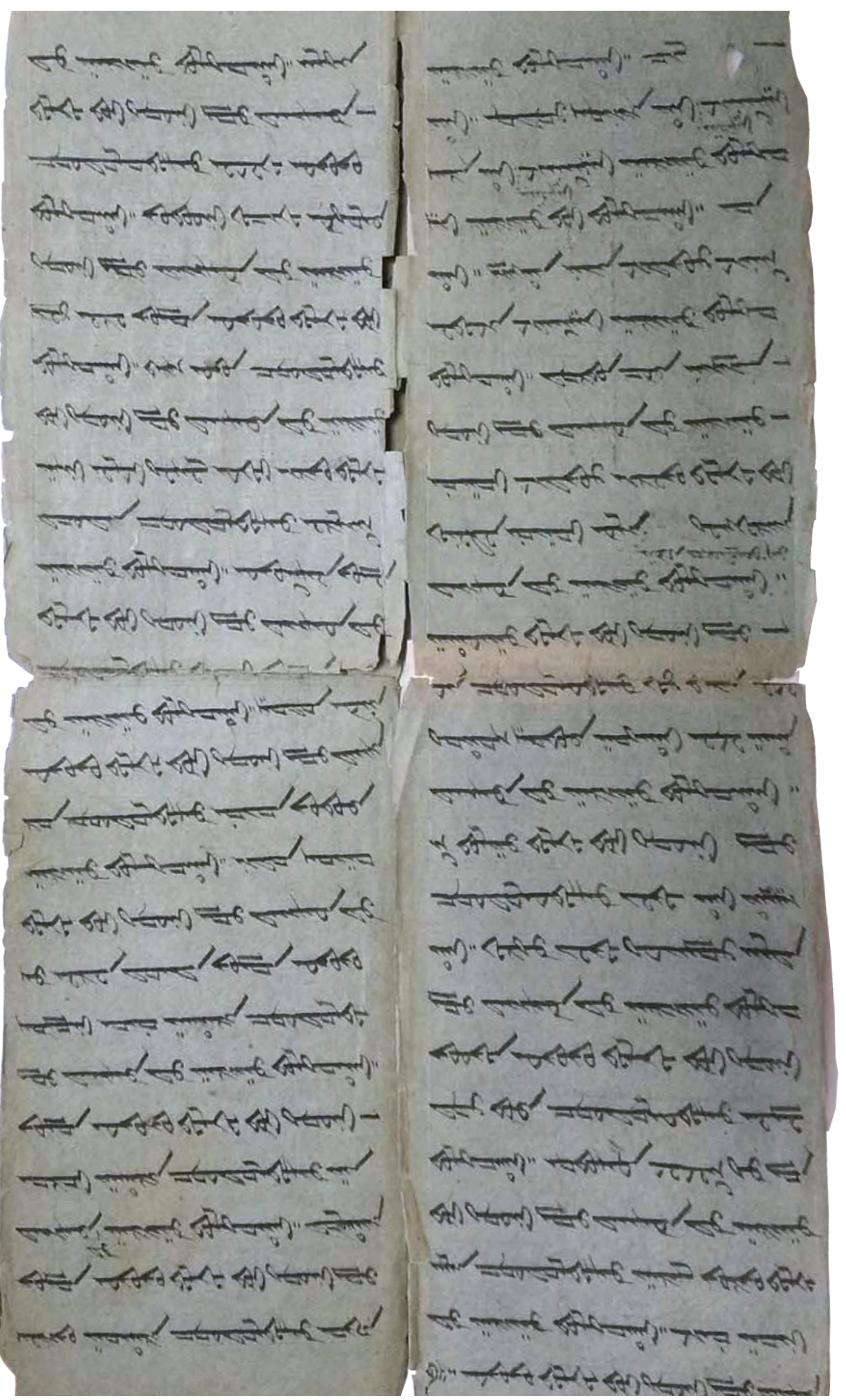




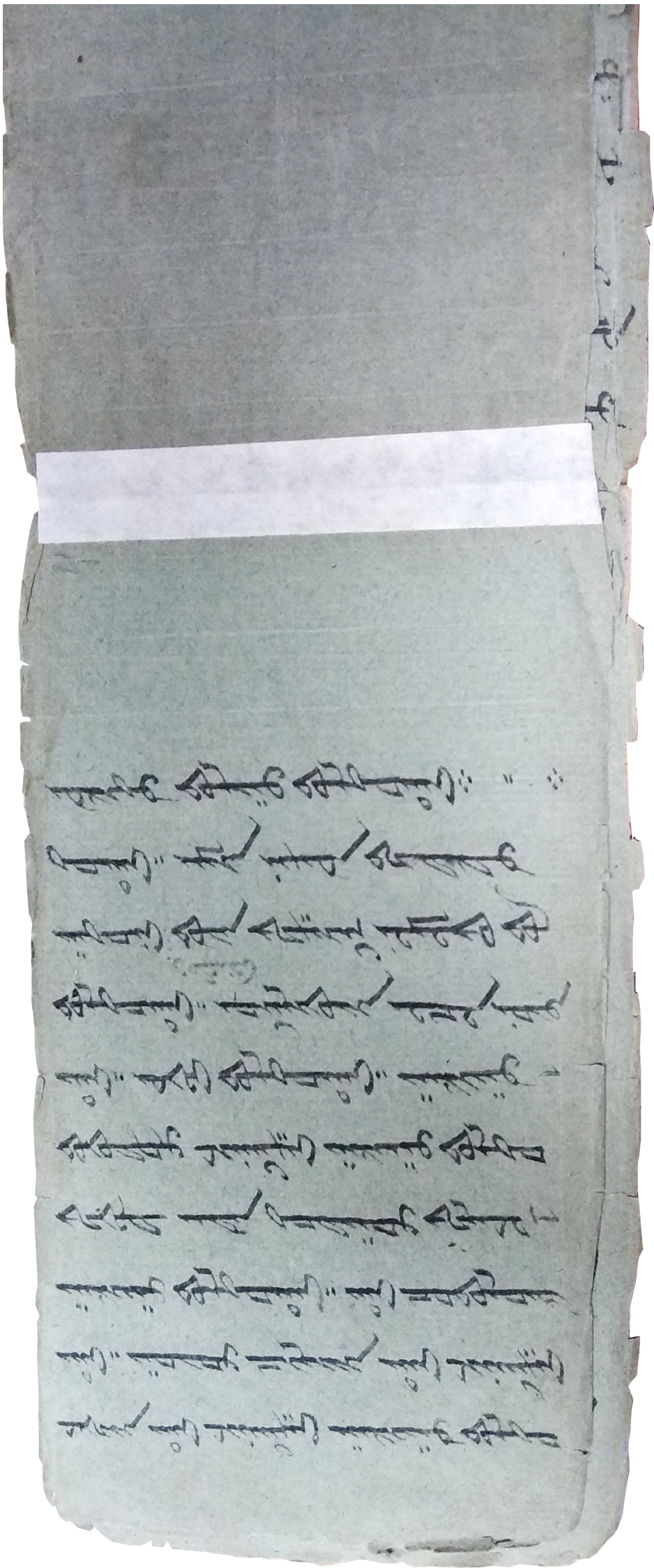

